\title{
Is there a link between globalisation and civil conflict?
}

\section{Roberto Ezcurra | Beatriz Manotas}

Department of Economics, Universidad Pública de Navarra, Pamplona, Spain

\section{1 | INTRODUCTION}

The consequences of globalisation are nowadays the subject of an active public debate in different forums (Milanovic, 2016; Rodrik, 2012). The interest surrounding this issue is clearly related to the increasing relevance of the process of globalisation currently underway. This does not imply that globalisation is a new phenomenon, as its origins go back to at least the nineteenth century (Findlay \& O'Rourke, 2007). Nevertheless, during the last few decades, the world has experienced unprecedented levels of integration, surpassing the peak reached before the First World War. This process is characterised by the opening of national borders to a variety of flows, including people, goods and services, capital, information and ideas (Clark, 2000). Although it is difficult to agree on a precise definition, there is wide consensus that globalisation tends to erode the relevance of national borders, generating complex relations among different actors at multicontinental distance (Norris, 2000). These increasing mutual interactions have important consequences on many relevant facets of contemporary societies, including economic, social, cultural and political aspects. Accordingly, understanding the effects of globalisation is essential to address the numerous challenges posed by this process, and be able to identify who wins and who loses, not only within each country but also across countries.

Against this background, numerous studies have been published in recent years on the impact of globalisation on economic development and growth (Dreher, 2006; Frankel \& Romer, 1999), income inequality and poverty (Dollar \& Kraay, 2004; Milanovic, 2005), labour markets (Dreher \& Gaston, 2007; Tomohara \& Takii, 2011), environmental quality (Antweiler, Copeland, \& Taylor, 2001; Frankel \& Rose, 2005), or democracy and human rights (Dreher, Gassebner, \& Siemers, 2012; Rudra, 2005). Likewise, there are various contributions that examine the potential link between globalisation and civil conflict using different indicators of trade openness and foreign direct investment to measure the relevance of globalisation (e.g., Bussmann \& Schneider, 2007; Martin, Mayer, \& Thoenig, 2008; Sorens \& Ruger, 2014). From a policy perspective, the relationship between these variables and civil conflict is clearly important, as it provides information on the role that economic integration plays in this context. Nevertheless, the degree of trade openness and foreign direct investment are not useful to capture the incidence of other dimensions of globalisation identified in the political economy literature, such as social integration and political integration (Keohane \& Nye, 2000; Prakash \& Hart, 1999). This is potentially important, given that it is 
not evident that the various dimensions of globalisation affect internal conflict in the same way. Bearing this in mind, and in a quest for empirically well-founded stylised facts, this paper aims to provide a comprehensive analysis of the relationship between globalisation and the incidence of civil conflict. We adopt a broader perspective than that found in most of the existing studies on this topic and investigate in a systematic way the consequences that the economic, social and political dimensions of globalisation have on civil conflict.

To the best of our knowledge, only Nieman (2011), Olzak (2011), and Flaten and de Soysa (2012) have thus far considered the multidimensional nature of the process of globalisation in this context. Nieman (2011) finds that changes in the degree of integration imply greater risk of internal conflict. The results of Olzak (2011) show that economic and cultural globalisation is positively associated with the intensity of ethnic conflicts, while sociotechnical aspects of integration increase fatalities from ethnic conflicts but decrease deaths from non-ethnic conflicts. Finally, the empirical evidence provided by Flaten and de Soysa (2012) suggests that globalisation, particularly economic and social globalisation, leads to lower risk of civil war.

These results are potentially important. Nevertheless, previous studies do not adequately address the potential endogeneity of the globalisation variables, which is particularly important to establish a causal link between the degree of integration with the rest of the world and civil conflict. In this paper, we use two strategies to tackle this issue. Our first strategy is to include in the analysis country fixed effects in order to control for those time-invariant factors affecting both conflict and globalisation, such as geographical and historical features. This is a first important difference between our paper and Nieman (2011), Olzak (2011), and Flaten and de Soysa (2012). While the fixed effects estimation is useful in removing the influence of long-run determinants of both conflict and globalisation, it does not necessarily estimate the causal effect of the degree of integration with the rest of the world on civil conflict. For this reason, unlike existing studies, our second strategy is to use an instrumental variables approach in this context. To that end, we construct an instrument for globalisation based on the degree of integration of neighbouring countries.

The paper also differs from Nieman (2011), Olzak (2011), and Flaten and de Soysa (2012) in the definition of conflict used in the analysis. Nieman (2011) and Flaten and de Soysa (2012) examine the impact of globalisation on the onset of civil war and respect for human rights, whereas the dependent variable used by Olzak (2011) is the number of fatalities from conflict, which is a measure of the intensity of conflict. In contrast, we are interested in the effect of integration on the incidence of civil conflict. This allows us to relate our paper to the abundant literature on the determinants of the incidence of intrastate conflicts (e.g., Esteban, Mayoral, \& Ray, 2012a,b; Miguel, Satyanath, \& Sergenti, 2004; Montalvo \& Reynal-Querol, 2005). Nevertheless, we also explore the robustness of our results with respect to conflict onset.

Unlike existing studies, we find no evidence of a significant impact of globalisation on civil conflict. The results of the paper show that the inclusion of country fixed effects removes the statistical association between the degree of integration with the rest of the world and the incidence of internal conflict. Our instrumental variables estimates also show no causal effect of globalisation on civil conflict. These findings do not depend either on the specific dimension of globalisation considered or the measure of conflict used in the analysis.

The remainder of the paper is organised as follows. After this introduction, Section 2 reviews several of the theoretical arguments proposed in the literature to justify the possible connection between globalisation and internal conflict. Section 3 describes the measures used in our study to quantify the relevance of globalisation and internal conflict in the various countries. Section 4 presents the empirical analysis undertaken to investigate the link between globalisation and civil 
conflict. The robustness of our findings is examined in Section 5. The main conclusions of our work are discussed in the final section.

\section{2 | THE RELATIONSHIP BETWEEN GLOBALISATION AND CIVIL CONFLICT}

From a theoretical perspective, there are several arguments to believe that globalisation and civil conflict may be related. Nevertheless, this is a complex relationship, as attempting to explain how globalisation affects conflict implies taking into consideration multiple factors and mechanisms that often work in opposite directions. Specifically, it is important to note that economic, social and political integration can have different effects on conflict (Flaten \& de Soysa, 2012; Nieman, 2011; Olzak, 2011).

Most of the existing literature has focussed exclusively on the link between international trade and civil conflict. According to Martin et al. (2008), there are two mechanisms relating trade and the opportunity cost of internal conflict, which work in opposite directions. The first of these mechanisms is the deterrence effect. This effect is based on the idea that the opportunity cost of conflict is positively associated with the degree of trade openness of the country in question, as the economic benefits generated by international trade can be threatened by the existence of intrastate violence. According to this effect, trade openness reduces the potential risk of civil conflict. However, Martin et al. (2008) also recall that international trade can be a substitute for internal trade during civil conflict episodes, thus acting as an insurance and reducing the opportunity cost of conflict. This insurance mechanism also implies the weakening of the degree of economic interdependence of the various regions and ethnic groups within a country, which in turn increases the feasibility of conflict (Martin et al., 2008). The final impact of international trade on the incidence of civil conflict depends ultimately on the magnitude of both effects, which may be related to the degree of intensity of conflict. The deterrence effect should be more relevant in high-intensity conflicts, whereas the insurance effect should be less important in this type of conflicts (Martin et al., 2008).

The opening of national economies to world markets has led to greater inequality in numerous countries (Milanovic, 2016). According to the traditional view, economic inequality is perceived as a major driver of social conflict. As pointed out by Sen (1973, p. 1), "the relationship between inequality and rebellion is indeed a close one". Yet, intuitive and natural as it might seem, the link between income inequality and conflict has not yet received conclusive and definitive empirical support (Esteban et al., 2012a,b). However, other dimensions of inequality are also potentially important in this context. For example, economic globalisation contributes to increasing spatial inequality (i.e., inequality across the various regions of a country; Ezcurra \& Rodríguez-Pose, 2014). This is particularly relevant in this context, since a high level of spatial inequality may lead to internal conflicts about the territorial distribution of resources (Deiwiks, Cederman, \& Gleditsch, 2012; Østby, Nordås, \& Rød, 2009). Furthermore, the impact of economic globalisation is often unevenly distributed across the members of different ethnic groups, favouring some groups over others and affecting ethnic inequality (i.e., inequality across ethnic groups; Olzak, 2011). The implications of economic globalisation on ethnic inequality are especially important in lower income countries, where the benefits from the process of integration tend to improve the relative situation of ethnic groups that hold a political dominant situation (Chua, 2003). To keep their privileged situation and limit the degree of mobilisation of disadvantaged groups, the dominant ethnic group usually adopts practices including the deterioration of civil and political rights of minority groups. This setting leads to an intensification of social unrest based on ethnic cleavages (Wimmer, 
Cederman, \& Min, 2009), which is consistent with the increasing relevance of violent ethnic conflicts in the last decades (Chua, 2003).

The social dimension of globalisation can also affect conflict. The flows of information and ideas that characterise social integration boost internal movements based on claims for self-determination and expanded minority rights (Flaten \& de Soysa, 2012; Olzak, 2011). Social globalisation contributes to reducing the cultural distance between countries, thus providing an ideological platform and an international audience predisposed to support these claims (Olzak, 2011). In this setting, minority groups have a greater capacity to mobilise against repressive regimes that deny them their rights, which in turn raises the risk of armed conflict. Moreover, the advances in this dimension of globalisation give rise to an increase in migratory flows across national borders (Goldberg \& Pavcnik, 2007). These migratory flows often lead to a negative reaction of native citizens and the aggravation of existing ethnic tensions.

Social globalisation also exerts greater international pressure on repressive regimes as a result of the increasing information available nowadays via the Internet and other global communication media (Dreher et al., 2012). In this context, the existence of a violent conflict within a country negatively affects the likelihood of receiving foreign investment and international aid. Indeed, this effect is particularly important in countries highly dependent on tourism, as the economic gains generated by tourism are put at risk due to the negative publicity of internal violence. This argument seems to suggest that this aspect of social globalisation increases the opportunity cost of civil conflict. However, at the same time, the advance of the new information technologies also enhances the mobilisation capacity of insurgents.

Finally, political globalisation may also be connected with the incidence of intrastate conflict through different mechanisms. An important aspect of this dimension of globalisation has to do 2 with the increasing relevance of supranational organisations such as the WTO, the IMF or regional trade unions. The decisions adopted by these organisations tend to be based on asymmetric trade and financial relations, which can affect the internal situation and the economic performance of low- and middle-income countries (Stiglitz, 2002). This may have implications on the level of dispersion of the income distribution, the degree of ethnic inequality or the magnitude of spatial disparities within these countries. As outlined above, all these factors are important in explaining the potential for social unrest and civil conflict.

Empirical research is key to illustrating the potential link between globalisation and conflict. In recent years, several studies have investigated this relationship empirically, paying particular attention to the impact of international trade and financial liberalisation on civil conflict (e.g., Bussmann \& Schneider, 2007; Martin et al., 2008; Sorens \& Ruger, 2014). These analyses are doubtless useful to examine the effect of economic globalisation on internal conflict, but they do not provide any information on the role played by social and political globalisation in this context. Although the different aspects of globalisation are often positively correlated, this omission is potentially important, as the various arguments discussed above show that social and political globalisation may have a direct effect on the incidence of conflict. Accordingly, the impact of economic integration on conflict observed in the literature may be affected by the omission of social and political globalisation from the analysis. Bearing this in mind, in this paper we follow the strategy adopted by Nieman (2011), Olzak (2011), and Flaten and de Soysa (2012) and use an extensive concept of globalisation, which allows us to comprehensively examine the overall effect of economic, social and political integration on civil conflict. Nevertheless, our research does not aim to propose a new theory or to test empirically the relevance of a specific channel linking globalisation and internal violence. As pointed out in the introduction, our main contribution to the literature has to do with the strategies adopted to investigate the causal link between the degree of integration with the rest of the world and civil conflict. 


\section{3 | MEASURING GLOBALISATION AND CIVIL CONFLICT}

Our empirical analysis requires comparable and reliable information on the incidence of globalisation in the various countries. Nevertheless, this is not an easy task because, as discussed above, globalisation is a multidimensional process and cannot be captured by a single variable (Clark,

3 2000; Keohane \& Nye, 2000). The measure of globalisation that we use is the KOF index of globalisation constructed by Dreher (2006) and updated by Dreher, Gaston, and Martens (2008). This is a composite index widely employed in the recent literature to examine different aspects of the consequences of globalisation. ${ }^{1}$

The KOF index is based on a set of 23 variables associated with different dimensions of globalisation. These variables are used to obtain three indices on the incidence of economic, social and political integration by means of principal component analysis (for further details see Dreher et al., 2008). The information provided by these three indices is employed to calculate an overall index of globalisation. The index of economic integration is a weighted average of two subindices that respectively measure actual economic flows and existing restrictions on trade and capital. The index of social integration is a weighted average of three subindices that respectively capture the importance of personal contacts, information flows and cultural proximity. The degree of political integration is proxied by the number of embassies in a country, membership in international organisations, participation in UN peacekeeping missions, and the ratification of international treaties. Finally, the overall index of globalisation is obtained as a weighted average of the three indices of economic, social and political integration. ${ }^{2}$ Table S2 in the online Appendix S1 displays the correlation coefficients between the overall measure of globalisation and the three indices of economic, social and political integration. As expected, all the correlation coefficients are positive and statistically significant at the $1 \%$ level. Their magnitude, however, reveals the existence of discrepancies between the various dimensions of globalisation identified by the KOF index. This shows that the distinction between economic, social and political globalisation is empirically relevant and is not only a conceptual issue.

To conduct the analysis, we also need to quantify the incidence of civil conflicts in the various countries. This information is drawn from the UCDP/PRIO Armed Conflict Dataset. We follow the common practice in the literature and take as our baseline PRIO25, which reports all internal conflicts with 25 or more battle-related deaths in a year (e.g., Esteban et al., 2012a,b; Miguel et al., 2004; Nunn \& Qian, 2014). According to this criterion, 92 countries experienced at least one episode of civil conflict between 1972 and 2009, which shows that intrastate violence is not concentrated in a small number of countries.

\section{4 | IS THERE AN EMPIRICAL LINK BETWEEN GLOBALISATION AND CIVIL CONFLICT?}

\subsection{The model}

In this section, we investigate the relationship between globalisation and civil conflict in 159 countries over the period 1972-2009. To that end, we estimate different versions of the following model:

\footnotetext{
'A comprehensive list of papers based on the KOF index of globalisation can be found at http://globalization.kof.ethz.ch/.

${ }^{2}$ Table S1 in the online Appendix S1 includes further details on the different components of the KOF index, as well as the weights attached to each individual variable to derive the various indices.
} 


$$
C_{i t}=\alpha+\beta C_{i t-1}+\gamma G_{i t-1}+\delta^{\prime} X_{i t-1}+\eta_{i}+\lambda_{t}+\varepsilon_{i t},
$$

where $C$ is a binary variable that takes a value of one if a civil conflict occurred in country $i$ during year $t$, zero otherwise. The lagged value of this variable is included on the right-hand side to capture the inherent persistence in conflicts. $G$ is the KOF index of globalisation described above, and $X$ denotes a set of variables that control for additional factors that are assumed to have an influence on civil conflict. In turn, $\eta$ stands for country-specific effects, while $\lambda$ are year dummies common to all countries. Finally, $\varepsilon$ is the corresponding disturbance term. The coefficient of interest throughout the paper is $\gamma$, which measures the effect of globalisation on the incidence of civil conflict.

The control variables included in vector $X$ have been selected on the basis of existing studies on the explanatory factors of civil conflict. ${ }^{3}$ Thus, there is an increasing body of research that shows the association between economic conditions and internal violence. The level of GDP per capita can be interpreted as a proxy for "a state's overall financial, administrative, police and military capabilities" (Fearon \& Laitin, 2003, p. 80), which suggests that rebels can expect a greater probability of success in low-income countries. Furthermore, episodes of conflict tend to be preceded by negative income shocks (Miguel et al., 2004). In fact, the lower the growth rate, the lower the opportunity cost of enlisting as a rebel and engaging in a civil conflict (Collier \& Hoeffler, 2004). Taking these arguments into account, we control for the level of GDP per capita and the growth rate of this variable, using data taken from the Penn-World Table (Heston, Summers, \& Aten, 2011). ${ }^{4}$

Democratic and autocratic states tend to have few civil conflicts, while intermediate regimes are the most conflict-prone (Fearon \& Laitin, 2003; Hegre, Ellingsen, Gates, \& Gleditsch, 2001). In view of this, we use a democracy index drawn from the Polity IV Project to construct two dummy variables to identify anocratic and democratic regimes (autocratic states are the omitted category). ${ }^{5}$ Natural resource abundance may also be related to civil conflict (e.g., Brunnschweiler \& Bulte, 2009; Ross, 2006). An unfair distribution of gains from natural resources could lead to social unrest and violence. Moreover, natural resources may provide an important source of funding for rebel forces, making conflict more feasible (Collier, Hoeffler, \& Rohner, 2009). Bearing this in mind, we include in our model the data on total natural resources rents (as a percentage of GDP) provided by the World Development Indicators. ${ }^{6}$

When considering the specification of model (1), it is important to note that the inclusion of country fixed effects allows us to control for those time-invariant elements relevant in this context, such as geographical and historical factors. As pointed out by Sunde and Cervellatti (2014), country fixed effects should also account for all potential determinants of civil violence in which most of the variation throughout the study period is across countries rather than over time. This is the case, for example, of the degree of ethnic diversity, population size or regional disparities. Many of these factors are also likely to be correlated with globalisation, which implies that removing the country fixed effects from model (1) may lead to biased and inconsistent estimates.

\footnotetext{
${ }^{3}$ See Blattman and Miguel (2010) and Hegre and Sambanis (2006) for surveys of this literature.

${ }^{4}$ Note that the inclusion of the level of GDP per capita and its growth rate in model (1) is debatable, as these variable may be considered as proximate outcomes of globalisation (Dreher, 2006; Frankel \& Romer, 1999). Nevertheless, the results of the paper are unaffected if we remove the level of GDP per capita and its growth rate from model (1).

${ }^{5}$ Although there are arguments suggesting that globalisation may also affect democracy, the available empirical evidence is far from being conclusive (Doces \& Magee, 2015; Rudra, 2005). In any case, we checked that our main findings still hold if we remove these dummies from the list of controls.

${ }^{6}$ Table S3 in the online Appendix S1 shows some descriptive statistics for the different variables used in the analysis.
} 


\section{2 | Results}

Table 1 presents the results obtained when various versions of model (1) are estimated with the KOF index as our measure of globalisation. Taking into account the approach adopted by Nieman (2011), Olzak (2011), and Flaten and de Soysa (2012), we begin by estimating the model without fixed effects, using a probit model and a linear probability model. As can be observed in columns 1 and 2, in both cases the coefficient of the globalisation index is negative and statistically significant, which seems to suggest that a higher level of integration with the rest of the world is associated with a lower incidence of civil conflict. This result would be consistent with those arguments defending that the advances of globalisation can help to promote stability and peace, and reduce the risks of internal conflicts (Barbieri \& Reuveny, 2005; Bhagwati, 2004). Nevertheless, although statistically significant, the effect of globalisation is quantitatively small. For example, the estimates in column 2 indicate that, conditional on the remaining covariates, a one standard deviation increase in the globalisation index is associated with a reduction of around $2 \%$ in the probability

4 of conflict. $^{7}$ However, if this pooled OLS regression identified the causal effect of globalisation on the incidence of civil conflict, then the long-run effect would be larger than this, because of the inclusion of the lagged dependent variable on the right-hand side. The implied cumulative effect of a one standard deviation increase in the globalisation index would reduce the probability of conflict by around 10\%. These findings should be treated with caution, as column 3 shows that the coefficient of the globalisation index is no longer statistically significant once country fixed effects are included in model (1). This suggests that the association between globalisation and civil conflict observed in columns 1 and 2 is driven by time-invariant omitted variables, such as historical and geographical factors. Table 1 around here

As mentioned in the introduction, fixed effects regressions do not necessarily identify the causal effect of globalisation on civil conflict. In fact, it is possible that $\operatorname{Cov}\left(G_{i t-1}, \varepsilon_{i t}\right) \neq 0$ because of the potential reverse impact of conflict on the spread of globalisation. The empirical evidence provided by Martin et al. (2008) shows that the destruction of trade due to civil conflicts can be quantitatively very important and persistent over time. In particular, in the case of civil wars with reported casualties over 50,000 deaths, these authors observe a fall in trade around $25 \%$ from its natural level in the first year of the war. The destruction of trade increases with time and it is still present at around 40\% 25 years after the conflict's onset. The effect is lower in magnitude but still present and persistent in the case of less-intensity conflicts (Martin et al., 2008). In addition to this reverse causality problem, there may be time-varying omitted determinants of conflict correlated with the degree of integration. Finally, the values of the globalisation index may be affected by measurement errors. All of these problems could be solved if we had a suitable instrument for globalisation. Such an instrument must not be correlated with the disturbance term in model (1), but account for the cross-country variation in the incidence of globalisation.

As pointed by Flaten and de Soysa (2012), finding an instrument that fulfils these two conditions is not an easy task in our context given the nature of the KOF index. While we do not have an ideal source of exogenous variation, we consider that the (weighted) average of the incidence of globalisation in neighbouring countries can be a plausible instrument. To calculate this average the values of the globalisation index are weighted by a spatial weights matrix, $W$, which describes the spatial interdependences among the sample countries. In particular, $W$ is defined as follows: 
T A B L E 1 Globalisation and conflict incidence: Main results

\begin{tabular}{|c|c|c|c|c|}
\hline & $\begin{array}{l}\text { Pooled Probit } \\
\text { (1) }\end{array}$ & $\begin{array}{l}\text { Pooled OLS } \\
\text { (2) }\end{array}$ & $\begin{array}{l}\text { FE-OLS } \\
\text { (3) }\end{array}$ & $\begin{array}{l}\text { FE-2SLS } \\
\text { (4) }\end{array}$ \\
\hline \multirow[t]{2}{*}{ Lagged conflict } & $2.805 * * *$ & $0.796 * * *$ & $0.599 * * *$ & $0.599 * * *$ \\
\hline & $(0.126)$ & $(0.025)$ & $(0.038)$ & $(0.037)$ \\
\hline \multirow[t]{2}{*}{ Overall index of globalisation } & $-0.014 * * *$ & $-0.001 * *$ & -0.001 & -0.002 \\
\hline & $(0.005)$ & $(0.000)$ & $(0.001)$ & $(0.003)$ \\
\hline \multirow[t]{2}{*}{ GDP per capita (log) } & 0.019 & 0.004 & 0.017 & 0.021 \\
\hline & $(0.060)$ & $(0.006)$ & $(0.016)$ & $(0.020)$ \\
\hline \multirow[t]{2}{*}{ Economic growth } & 0.434 & 0.051 & 0.022 & 0.022 \\
\hline & $(0.495)$ & $(0.076)$ & $(0.076)$ & $(0.074)$ \\
\hline \multirow[t]{2}{*}{ Democracy } & 0.160 & 0.015 & 0.004 & 0.005 \\
\hline & $(0.113)$ & $(0.011)$ & $(0.019)$ & $(0.019)$ \\
\hline \multirow[t]{2}{*}{ Anocracy } & $0.285^{* * *}$ & $0.029 * *$ & $0.044 * *$ & $0.043 * *$ \\
\hline & $(0.087)$ & $(0.011)$ & $(0.019)$ & $(0.019)$ \\
\hline \multirow[t]{2}{*}{ Natural resources } & 0.000 & -0.000 & -0.000 & -0.000 \\
\hline & $(0.002)$ & $(0.000)$ & $(0.001)$ & $(0.001)$ \\
\hline Country fixed effects & No & No & Yes & Yes \\
\hline Year dummies & Yes & Yes & Yes & Yes \\
\hline$R^{2}$ & $0.588^{\mathrm{a}}$ & 0.654 & 0.694 & 0.693 \\
\hline Root mean square error & - & 0.221 & 0.212 & 0.207 \\
\hline Countries & 159 & 159 & 159 & 159 \\
\hline Observations & 4,864 & 4,864 & 4,864 & 4,864 \\
\hline
\end{tabular}

Notes: The dependent variable is a binary variable that takes a value of one for conflicts with 25 or more battle-related deaths in a year, zero otherwise (PRIO25). Robust standard errors clustered at the country level in parentheses.

${ }^{\text {a}}$ Pseudo $R^{2}$.

*Significant at $10 \%$ level, $* *$ significant at $5 \%$ level, $* * *$ significant at $1 \%$ level.

$$
W=\left\{\begin{array}{c}
w_{i j}=0 \text { if } \mathrm{i}=\mathrm{j} \\
w_{i j}=\frac{1 / d_{i j}^{2}}{\sum_{j} 1 / d_{i j}^{2}} \text { if } \mathrm{i} \neq \mathrm{j},
\end{array}\right.
$$

where $d_{i j}$ is the geographical distance between countries $i$ and $j$, which in itself is strictly exogenous. As can be observed, $W$ is row standardised, so that it is relative and not absolute distance which matters. Analogously, one can calculate the (weighted) average of the degree of economic, social and political globalisation in neighbouring countries. The rationale for using this instrument has to do with the notion that geography and spatial interdependence are important factors for the spread of globalisation, which is consistent, for example, with numerous theoretical models developed in the so-called "New Economic Geography" (e.g., Fujita \& Thisse, 2002; Krugman, 1998). There is abundant evidence showing that trade flows are more likely between neighbouring countries, as transport costs increase with geographical distance (e.g., Anderson \& Van Wincoop, 2004; Disdier \& Head, 2008). Similarly, the cultural distance between two countries depends directly on the geographical distance between them (Disdier, Tai, Fontagné; \& Mayer, 2010). These arguments 
suggest that a country's level of globalisation tends to be higher, the higher the degree of integration of its neighbouring countries with the rest of the world.

The first-stage regressions in Table 2 confirm the relevance of the instrument in explaining the cross-country variation in the incidence of globalisation. The coefficient of the instrument is in all cases positive and statistically significant at the $1 \%$ level, regardless of the specific dimension of globalisation considered. The partial regression plots displayed in Figure $\mathrm{S} 1$ in the online

TA B L E 2 First-stage regressions

\begin{tabular}{|c|c|c|c|c|}
\hline Dependent variable & $\begin{array}{l}\text { (1) } \\
\text { Overall } \\
\text { globalisation }\end{array}$ & $\begin{array}{l}\text { (2) } \\
\text { Economic } \\
\text { globalisation }\end{array}$ & $\begin{array}{l}\text { (3) } \\
\text { Social } \\
\text { globalisation }\end{array}$ & $\begin{array}{l}(4) \\
\text { Political } \\
\text { globalisation }\end{array}$ \\
\hline $\begin{array}{l}\text { Overall globalisation in } \\
\text { neighbouring countries }\end{array}$ & $\begin{array}{l}0.346 * * * \\
(0.053)\end{array}$ & & & \\
\hline $\begin{array}{l}\text { Economic globalisation in } \\
\text { neighbouring countries }\end{array}$ & & $\begin{array}{l}0.348^{* * *} \\
(0.070)\end{array}$ & & \\
\hline $\begin{array}{l}\text { Social globalisation in } \\
\text { neighbouring countries }\end{array}$ & & & $\begin{array}{l}0.433 * * * \\
(0.069)\end{array}$ & \\
\hline $\begin{array}{c}\text { Political globalisation in } \\
\text { neighbouring countries }\end{array}$ & & & & $\begin{array}{l}0.395 * * * \\
(0.109)\end{array}$ \\
\hline Lagged conflict & $\begin{array}{r}-0.266 \\
(0.367)\end{array}$ & $\begin{array}{r}-0.126 \\
(0.740)\end{array}$ & $\begin{array}{r}-0.448 \\
(0.431)\end{array}$ & $\begin{array}{c}-0.482 \\
(-0.837)\end{array}$ \\
\hline GDP per capita (log) & $\begin{array}{l}2.731 * * * \\
(0.995)\end{array}$ & $\begin{array}{c}1.425 \\
(1.403)\end{array}$ & $\begin{array}{l}4.037 * * * \\
(1.063)\end{array}$ & $\begin{array}{c}2.400 \\
(1.516)\end{array}$ \\
\hline Economic growth & $\begin{array}{l}0.491 \\
(1.082)\end{array}$ & $\begin{array}{l}5.211 * * \\
(2.035)\end{array}$ & $\begin{array}{c}-2.718 * * \\
(1.176)\end{array}$ & $\begin{array}{c}1.476 \\
(1.971)\end{array}$ \\
\hline Democracy & $\begin{array}{l}1.189 * \\
(0.616)\end{array}$ & $\begin{array}{c}1.812 \\
(1.040)\end{array}$ & $\begin{array}{r}-0.154 \\
(0.821)\end{array}$ & $\begin{array}{l}3.003 * * \\
(1.333)\end{array}$ \\
\hline Anocracy & $\begin{array}{r}-0.677 \\
(0.479)\end{array}$ & $\begin{array}{r}-0.678 \\
(0.745)\end{array}$ & $\begin{array}{c}-2.300 * * * \\
(0.548)\end{array}$ & $\begin{array}{l}2.054 * \\
(1.052)\end{array}$ \\
\hline Natural resources & $\begin{array}{r}-0.030 \\
(0.024)\end{array}$ & $\begin{array}{l}0.079 * * \\
(0.033)\end{array}$ & $\begin{array}{c}-0.068 * * \\
(0.027)\end{array}$ & $\begin{array}{r}-0.042 \\
(0.033)\end{array}$ \\
\hline Country fixed effects & Yes & Yes & Yes & Yes \\
\hline Year dummies & Yes & Yes & Yes & Yes \\
\hline$+>$ & 0.970 & 0.939 & 0.965 & 0.907 \\
\hline Root mean square error & 3.232 & 4.910 & 4.126 & 6.900 \\
\hline$F$-test excluded instrument & $43.17 * * *$ & $24.38 * * *$ & $38.88 * * *$ & $13.25 * * *$ \\
\hline Partial $R^{2}$ & 0.110 & 0.070 & 0.155 & 0.040 \\
\hline Countries & 159 & 139 & 159 & 160 \\
\hline Observations & 4,864 & 4,431 & 4,864 & 4,884 \\
\hline Second-stage results & Table 1, col. 4 & Table 3 , col. 3 & Table 3, col. 6 & Table 3, col. 9 \\
\hline
\end{tabular}

Notes: Robust standard errors clustered at the country level in parentheses.

*Significant at $10 \%$ level, ** significant at $5 \%$ level, *** significant at $1 \%$ level. 
Appendix S1 indicate that the association between the instrument and the degree of globalisation is not driven by potential outliers. Furthermore, the values of the $F$-statistic for the excluded instrument shown in Table 2 suggest that there is no reason to believe that our estimates are biased by a weak instrument.

To be a valid instrument, however, the degree of globalisation in neighbouring countries should not affect the incidence of conflict in any given country beyond its impact on the level of globalisation of that country. This condition cannot be tested formally in the absence of other instruments, but we consider that it is a plausible assumption. Nevertheless, one may argue that the degree of integration of neighbouring countries may influence the dependent variable in model (1) through cross-border conflict spillovers. However, as can be seen in Section 5, our main results still hold when we control for the incidence of conflict in neighbouring countries.

Column 4 of Table 1 reports the 2SLS estimates of model (1). ${ }^{8}$ The results reveal the absence of a significant relationship between globalisation and civil conflict, thus confirming the information provided by the OLS estimates with fixed effects in column 3 of Table 1. Therefore, our analysis shows no evidence on the existence of causal effect of the degree of integration with the rest of the world on intrastate conflict, which should be taken into account by policymakers and international organisations when considering the consequences associated with the process of globalisation currently underway.

With respect to the control variables included in model (1), Table 1 reveals that conflict incidence is deeply affected by the existence of previous episodes of violence. ${ }^{9}$ In turn, civil conflict is more likely in anocratic regimes, which is consistent with the empirical evidence provided by Hegre et al. (2001) and Fearon and Laitin (2003), among others. The remaining covariates are not significantly related to conflict incidence in our regressions.

So far we have investigated the overall impact of globalisation on the incidence of civil conflicts. To complement our results, in Table 3, we use the information provided by the KOF index to examine the role played in this setting by economic, social and political integration. This is particularly interesting, given that it is not clear a priori that these three dimensions of globalisation affect civil conflict in the same way. We begin the analysis by discussing the OLS estimates of model (1) without country fixed effects. This specification shows that the measures of economic and social globalisation seem to be negatively and significantly associated with conflict incidence. The existence of a negative relationship between economic globalisation and intrastate conflict is in line with the findings reported by Barbieri and Reuveny (2005), Bussmann and Schneider (2007) or Flaten and de Soysa (2012), but it contrasts with the results in Martin et al. (2008) and Olzak (2011). The empirical evidence provided by Olzak (2011) indicates that cultural and sociotechnical aspects of integration increase the number of fatalities in ethnic conflicts. However, in the case of non-ethnic conflicts, she finds that sociotechnical aspects of globalisation are negatively correlated with casualties. In turn, the results reported by Flaten and de Soysa (2012) suggest that social globalisation reduces the risk of conflict onset. Table 3 also shows that the measure of political globalisation is positively and significantly related to the dependent variable.

\footnotetext{
${ }^{8}$ As pointed out by Miguel et al. (2004), 2SLS is typically preferred even in cases in which the dependent variable is dichotomous (Angrist \& Kreuger, 2001), as strong specification assumptions are required to justify the use of alternative methods, such as those proposed by Rivers and Vuong (1988).

'Note that including the lagged of the dependent variable on the right-hand side is unlikely to result in the Nickell (1981) bias, as the time dimension of our panel is relatively large $(T=38)$. Using Monte Carlo simulations, Judson and Owen (1999) and Beck and Katz (2004) show the limited influence of the lagged dependent variable on other covariates when the time dimension is moderately large.
} 


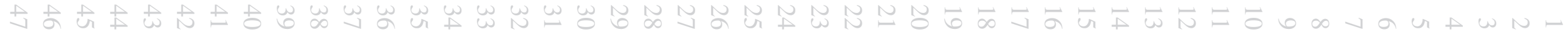

TA B LE 3 The various dimensions of globalisation and conflictincidence

\begin{tabular}{|c|c|c|c|c|c|c|c|c|c|c|c|c|}
\hline & $\begin{array}{l}\text { Pooled } \\
\text { OLS } \\
(1)\end{array}$ & $\begin{array}{l}\text { FE-OLS } \\
(2)\end{array}$ & $\begin{array}{l}\text { FE-2SLS } \\
\text { (3) }\end{array}$ & $\begin{array}{l}\text { Pooled } \\
\text { OLS } \\
(4)\end{array}$ & $\begin{array}{l}\text { FE-OLS } \\
(5)\end{array}$ & $\begin{array}{l}\text { FE-2SLS } \\
\text { (6) }\end{array}$ & $\begin{array}{l}\text { Pooled } \\
\text { OLS } \\
(7)\end{array}$ & $\begin{array}{l}\text { FE-OLS } \\
(8)\end{array}$ & $\begin{array}{l}\text { FE-2SLS } \\
(9)\end{array}$ & $\begin{array}{l}\text { Pooled } \\
\text { OLS } \\
(10)\end{array}$ & $\begin{array}{l}\text { FE-OLS } \\
(11)\end{array}$ & $\begin{array}{l}\text { FE-2SLS } \\
\text { (12) }\end{array}$ \\
\hline $\begin{array}{l}\text { Lagged } \\
\text { conflict }\end{array}$ & $\begin{array}{l}0.805^{* * *} \\
(0.026)\end{array}$ & $\begin{array}{l}0.618 * * * \\
(0.039)\end{array}$ & $\begin{array}{l}0.618 * * * \\
(0.038)\end{array}$ & $\begin{array}{l}0.791 \text { *** } \\
(0.025)\end{array}$ & $\begin{array}{l}0.599 * * * \\
(0.038)\end{array}$ & $\begin{array}{l}0.599 * * * \\
(0.037)\end{array}$ & $\begin{array}{l}0.796 * * * \\
(0.025)\end{array}$ & $\begin{array}{l}0.601 * * * \\
(0.037)\end{array}$ & $\begin{array}{l}0.602 * * * \\
(0.036)\end{array}$ & $\begin{array}{l}0.801 * * * \\
(0.025)\end{array}$ & $\begin{array}{l}0.617 * * * \\
(0.039)\end{array}$ & $\begin{array}{l}0.618 * * * \\
(0.040)\end{array}$ \\
\hline $\begin{array}{l}\text { Economic } \\
\text { globalisation }\end{array}$ & $\begin{array}{c}-0.001 * * * \\
(0.000)\end{array}$ & $\begin{array}{r}-0.001 \\
(0.001)\end{array}$ & $\begin{array}{r}-0.001 \\
(0.002)\end{array}$ & & & & & & & $\begin{array}{c}-0.001 * \\
(0.000)\end{array}$ & $\begin{array}{l}-0.00 \\
(0.001)\end{array}$ & $\begin{array}{c}0.002 \\
(0.014)\end{array}$ \\
\hline $\begin{array}{l}\text { Social } \\
\text { globalisation }\end{array}$ & & & & $\begin{array}{c}-0.002 * * * \\
(0.000)\end{array}$ & $\begin{array}{r}-0.001 \\
(0.001)\end{array}$ & $\begin{array}{r}-0.002 \\
(0.002)\end{array}$ & & & & $\begin{array}{c}-0.001 * * \\
(0.000)\end{array}$ & $\begin{array}{r}-0.001 \\
(0.001)\end{array}$ & $\begin{array}{r}-0.003 \\
(0.012)\end{array}$ \\
\hline $\begin{array}{l}\text { Political } \\
\text { globalisation }\end{array}$ & & & & & & & $\begin{array}{l}0.001 * * \\
(0.000)\end{array}$ & $\begin{array}{r}-0.000 \\
(0.001)\end{array}$ & $\begin{array}{c}0.002 \\
(0.002)\end{array}$ & $\begin{array}{c}0.001 * \\
(0.000)\end{array}$ & $\begin{array}{r}-0.000 \\
(0.001)\end{array}$ & $\begin{array}{c}0.002 \\
(0.002)\end{array}$ \\
\hline $\begin{array}{l}\text { GDP per } \\
\text { capita }(\log )\end{array}$ & $\begin{array}{c}0.003 \\
(0.005)\end{array}$ & $\begin{array}{c}0.004 \\
(0.020)\end{array}$ & $\begin{array}{c}0.004 \\
(0.021)\end{array}$ & $\begin{array}{l}0.013 * * \\
(0.007)\end{array}$ & $\begin{array}{c}0.019 \\
(0.017)\end{array}$ & $\begin{array}{c}0.023 \\
(0.020)\end{array}$ & $\begin{array}{c}-0.013^{* * *} \\
(0.005)\end{array}$ & $\begin{array}{c}0.010 \\
(0.016)\end{array}$ & $\begin{array}{c}0.004 \\
(0.018)\end{array}$ & $\begin{array}{c}0.010 \\
(0.008)\end{array}$ & $\begin{array}{c}0.012 \\
(0.020)\end{array}$ & $\begin{array}{c}0.006 \\
(0.046)\end{array}$ \\
\hline $\begin{array}{l}\text { Economic } \\
\text { growth }\end{array}$ & $\begin{array}{c}0.108 \\
(0.081)\end{array}$ & $\begin{array}{c}0.043 \\
(0.084)\end{array}$ & $\begin{array}{c}0.046 \\
(0.084)\end{array}$ & $\begin{array}{c}0.044 \\
(0.075)\end{array}$ & $\begin{array}{c}0.017 \\
(0.075)\end{array}$ & $\begin{array}{c}0.014 \\
(0.074)\end{array}$ & $\begin{array}{c}0.065 \\
(0.076)\end{array}$ & $\begin{array}{c}0.029 \\
(0.075)\end{array}$ & $\begin{array}{c}0.026 \\
(0.075)\end{array}$ & $\begin{array}{c}0.099 \\
(0.082)\end{array}$ & $\begin{array}{c}0.038 \\
(0.084)\end{array}$ & $\begin{array}{c}0.016 \\
(0.141)\end{array}$ \\
\hline Democracy & $\begin{array}{c}0.016 \\
(0.011)\end{array}$ & $\begin{array}{c}0.004 \\
(0.019)\end{array}$ & $\begin{array}{c}0.004 \\
(0.019)\end{array}$ & $\begin{array}{c}0.013 \\
(0.011)\end{array}$ & $\begin{array}{c}0.002 \\
(0.019)\end{array}$ & $\begin{array}{c}0.001 \\
(0.019)\end{array}$ & $\begin{array}{c}0.002 \\
(0.011)\end{array}$ & $\begin{array}{c}0.002 \\
(0.019)\end{array}$ & $\begin{array}{r}-0.004 \\
(0.020)\end{array}$ & $\begin{array}{c}0.011 \\
(0.011)\end{array}$ & $\begin{array}{c}0.002 \\
(0.019)\end{array}$ & $\begin{array}{r}-0.011 \\
(0.029)\end{array}$ \\
\hline Anocracy & $\begin{array}{l}0.031 \text { *** } \\
(0.011)\end{array}$ & $\begin{array}{l}0.044 * * \\
(0.019)\end{array}$ & $\begin{array}{l}0.043 * * \\
(0.019)\end{array}$ & $\begin{array}{l}0.027 * * \\
(0.011)\end{array}$ & $\begin{array}{l}0.042 * * \\
(0.019)\end{array}$ & $\begin{array}{l}0.040 * * \\
(0.020)\end{array}$ & $\begin{array}{c}0.020 * \\
(0.011)\end{array}$ & $\begin{array}{l}0.045^{* *} \\
(0.019)\end{array}$ & $\begin{array}{c}0.041 * * \\
(0.019)\end{array}$ & $\begin{array}{l}0.027 * * \\
(0.011)\end{array}$ & $\begin{array}{l}0.041 * * \\
(0.019)\end{array}$ & $\begin{array}{c}0.036 \\
(0.024)\end{array}$ \\
\hline $\begin{array}{l}\text { Natural } \\
\text { resources }\end{array}$ & $\begin{array}{c}0.000 \\
(0.000)\end{array}$ & $\begin{array}{c}0.001 \\
(0.001)\end{array}$ & $\begin{array}{c}0.001 \\
(0.001)\end{array}$ & $\begin{array}{r}-0.000 \\
(0.000)\end{array}$ & $\begin{array}{r}-0.000 \\
(0.001)\end{array}$ & $\begin{array}{r}-0.000 \\
(0.001)\end{array}$ & $\begin{array}{c}0.000 \\
(0.000)\end{array}$ & $\begin{array}{r}-0.000 \\
(0.001)\end{array}$ & $\begin{array}{c}-0.000 \\
(0.001)\end{array}$ & $\begin{array}{c}0.000 \\
(0.000)\end{array}$ & $\begin{array}{r}0.001 \\
(0.001)\end{array}$ & $\begin{array}{c}0.001 \\
(0.002)\end{array}$ \\
\hline $\begin{array}{l}\text { Country } \\
\text { fixed } \\
\text { effects }\end{array}$ & No & Yes & Yes & No & Yes & Yes & No & Yes & Yes & No & Yes & Yes \\
\hline $\begin{array}{l}\text { Year } \\
\text { dummies }\end{array}$ & Yes & Yes & Yes & Yes & Yes & Yes & Yes & Yes & Yes & Yes & Yes & Yes \\
\hline
\end{tabular}




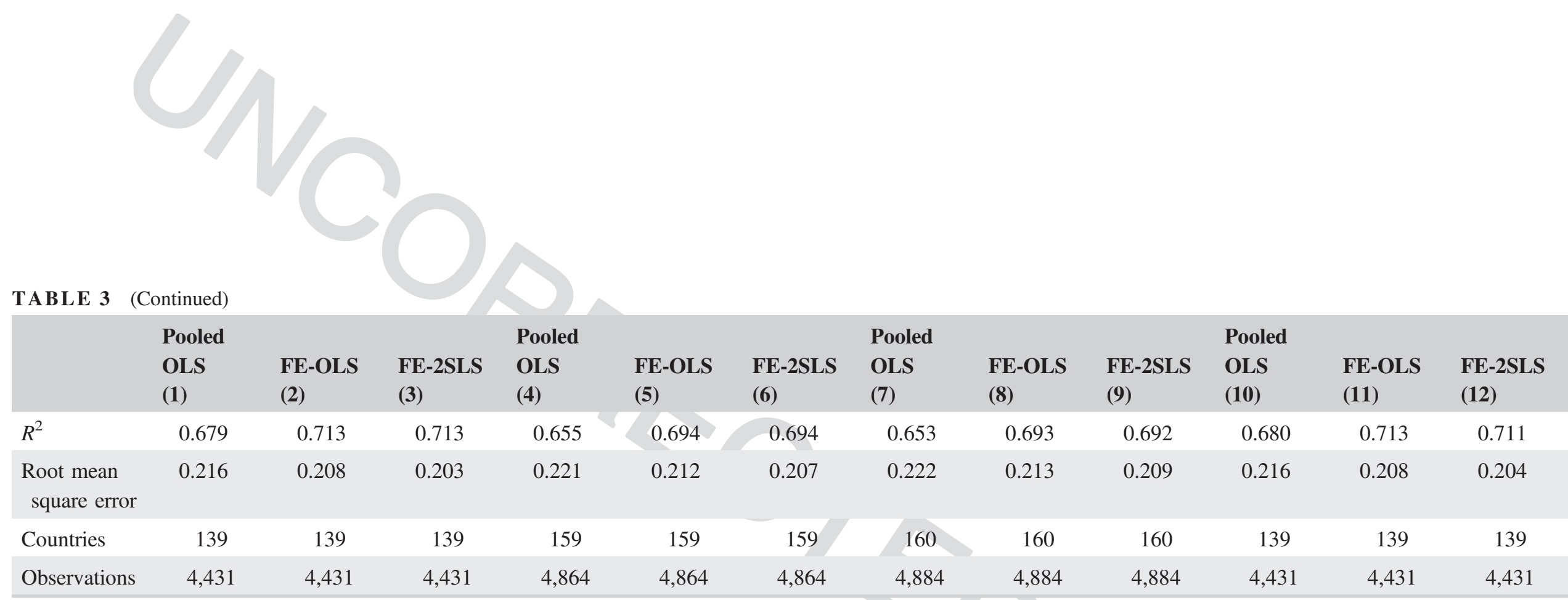

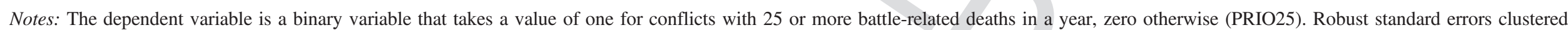
at the country level in parentheses.

*Significant at $10 \%$ level, ${ }^{* *}$ significant at $5 \%$ level, $* * *$ significant at $1 \%$ level. 
Nevertheless, the employment of alternative estimation strategies sheds considerable doubt on these findings. In fact, the estimates in Table 3 reveal that, once country fixed effects are introduced in the model and 2SLS regressions are used, the relationship between the various measures of globalisation and civil conflict disappears, which is consistent with our previous findings.

\section{5 | ROBUSTNESS CHECKS}

The analysis carried out so far suggests that the degree of integration with the rest of the world does not exert a significant effect on conflict incidence, regardless of the specific dimension of globalisation considered. In this section, we investigate the robustness of this result.

\section{1 | Influential countries}

We begin by examining whether our findings are robust to the elimination of regions that can be considered especially conflictive. As is known, civil conflicts have been particularly persistent during the last decades in sub-Saharan Africa, Asia and Latin America. We carry out different estimations of model (1) in which we exclude the countries in these regions in turn. Table S4 in the online Appendix S1 shows that our findings are not driven by countries located in the most conflictive regions in the world. Table S4 also reveals that the results still hold when we remove from the sample the high-income countries according to the World Bank classification.

\section{2 | Cross-border conflict spillovers and the exclusion restriction}

The exclusion restriction implied by our 2SLS regressions is that, conditional on the set of controls included in the baseline specification of model (1), the instrument has no effect on the incidence of civil conflict, other than their impact through globalisation. As mentioned above, the validity of this assumption may be problematic in the case of the globalisation of neighbouring countries, as one may argue that this variable could be correlated with the level of violence registered by neighbouring countries within their borders, which could in turn affect the risk of civil conflict in a particular country. In this line, the international relations literature has highlighted that conflict in one nation can cause violence in neighbouring countries in many different ways (Brown, 1996; Lake \& Rothchild, 1998). As an example, we might mention the existence of refugee flows or armed rebel groups seeking protection or wreaking havoc on neighbouring states to internationalise the conflict, alliances between transnational ethnic groups, or territorial demands involving two different nations. In fact, the empirical relevance of these cross-border conflict spillovers has been confirmed by several studies (e.g., Bosker \& de Ree, 2014; Buhaug \& Gleditsch, 2008; Hegre \& Sambanis, 2006).

In view of this, we now control for the incidence of conflict in neighbouring countries in the previous year. ${ }^{10}$ Table 4 presents the results obtained when this additional covariate is included in our baseline specification. As can be seen, the presence of a civil conflict in neighbouring countries seems to have a positive and statistically significant effect on conflict incidence, which is consistent with the existence of cross-border conflict spillovers. Nevertheless, Table 4 shows that the

\footnotetext{
${ }^{10}$ This variable has been constructed following the same method described in Section 4.2 to calculate the degree of globalisation in neighbouring countries.
} 


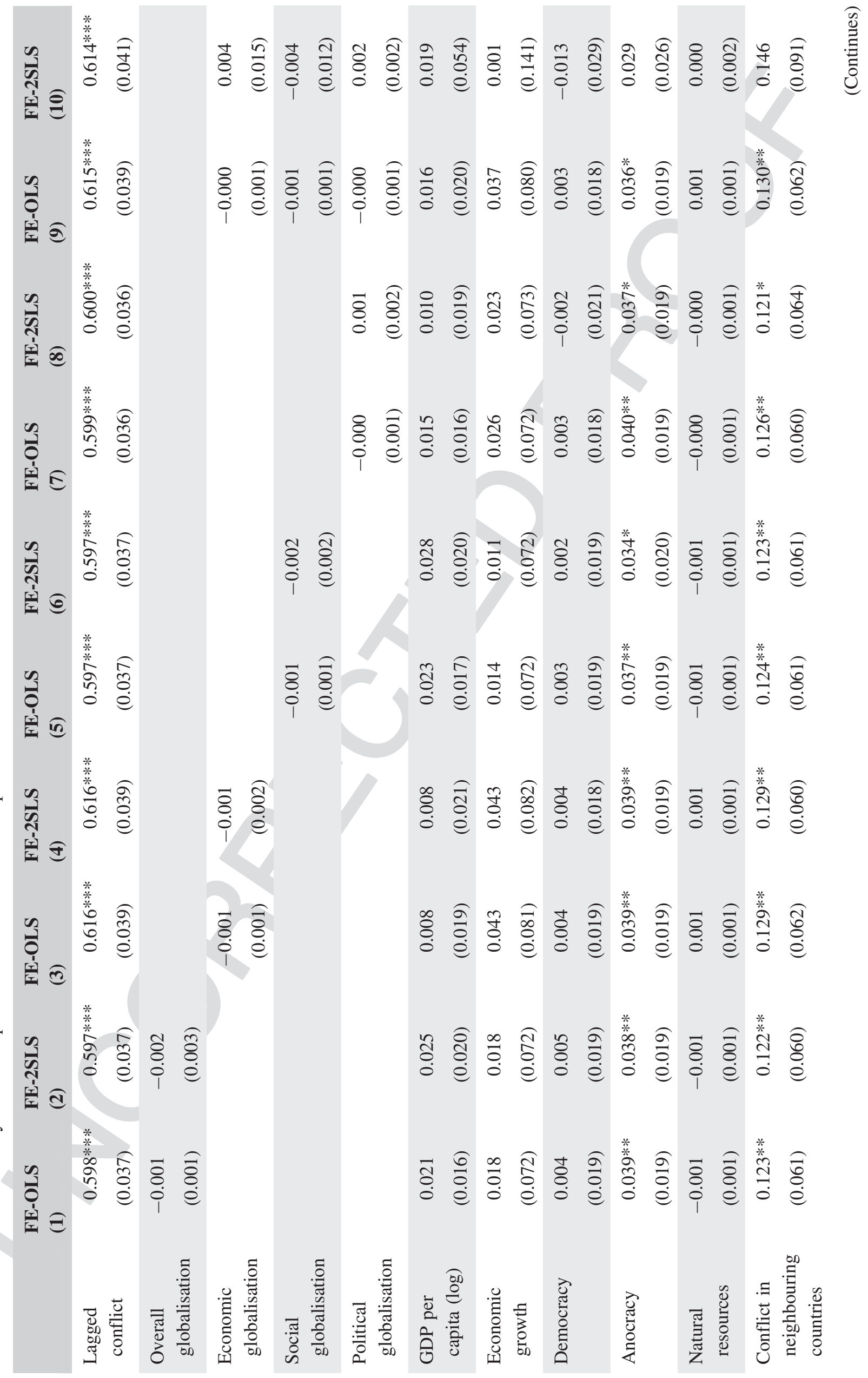




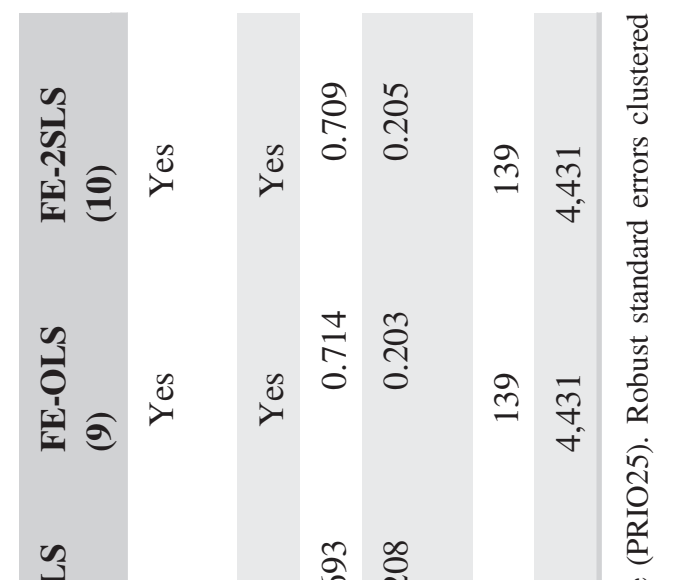

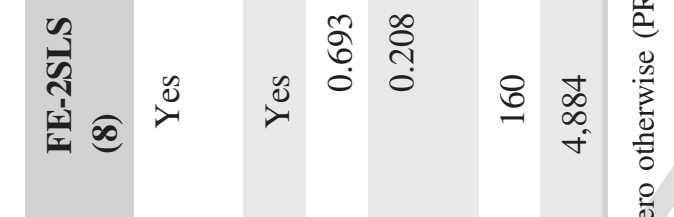

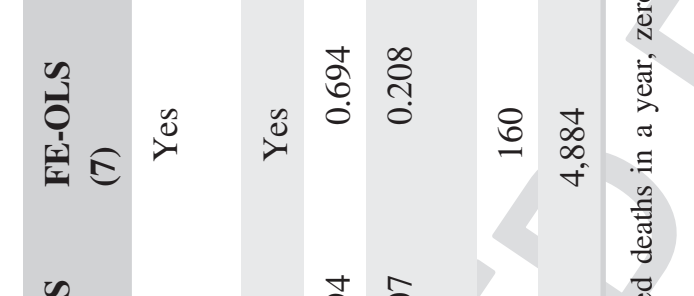

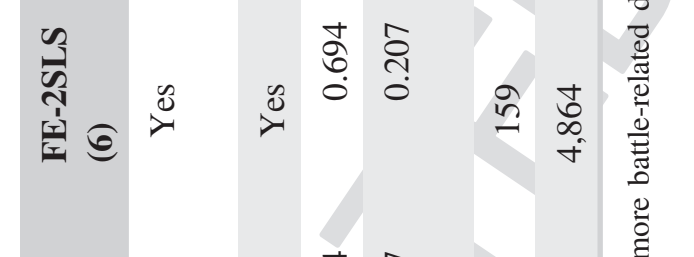

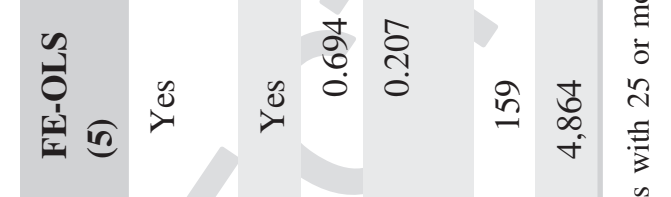

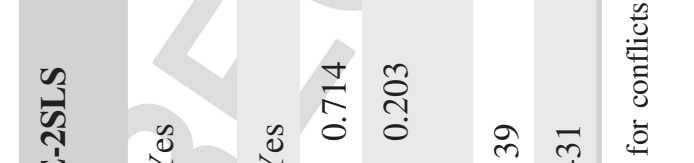

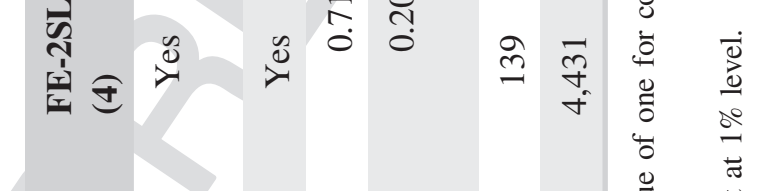

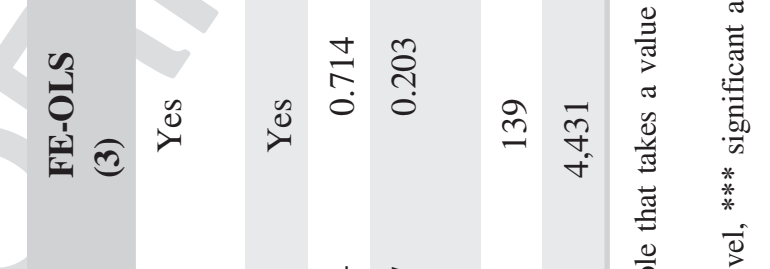

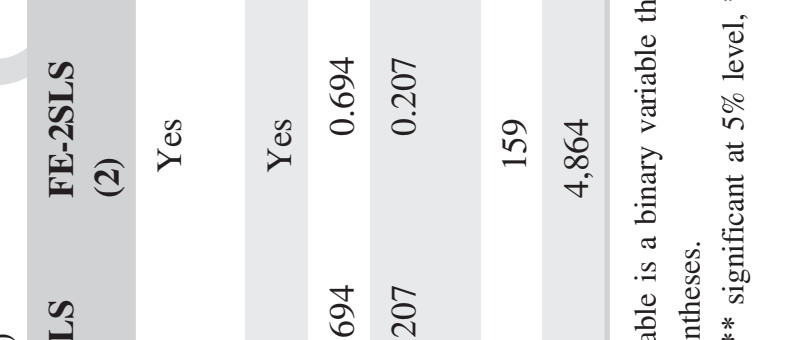

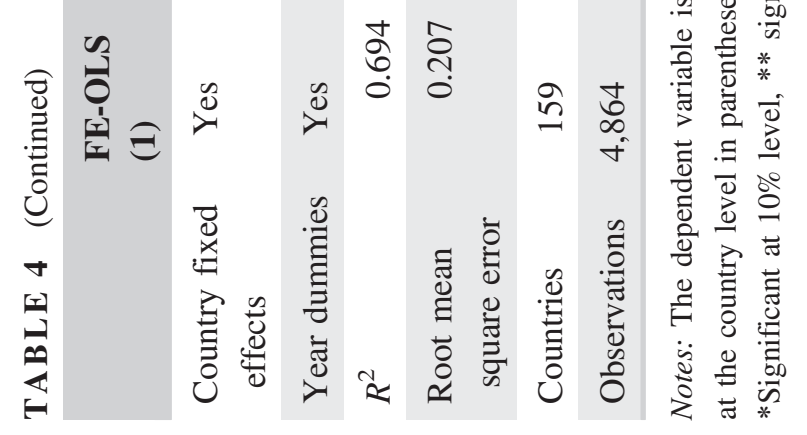


inclusion of this additional control in model (1) does not affect the previous results on the impact of globalisation on civil conflict, thus confirming the robustness of our findings. ${ }^{11}$

\section{3 | Alternative measures of conflict}

As mentioned above, the dependent variable in model (1) is PRIO25, a binary variable that reports conflicts with 25 or more battle-related deaths in a given year. Our findings, however, may be affected by the choice of this specific threshold of deaths. For this reason, as an additional robustness check, we now examine to what extent the previous results depend on the definition of civil conflict used to construct the dependent variable in model (1). To that end, we now use two alternative indicators based on the UCDP/PRIO data. The first one is PRIO25 augmented by the requirement that the conflict must yield at least 1,000 deaths over its course (PRIOCW). The second one considers exclusively conflicts with 1,000 or more deaths per year (PRIO1000), which allows us to focus on high-intensity conflicts. Table S6 in the online Appendix S1 presents the results obtained when PRIOCW and PRIO1000 are used as dependent variables. As can be seen, the estimates continue to show no significant relationship between globalisation and conflict incidence.

The analysis performed so far examines the effect of the degree of integration with the rest of the world on conflict incidence. However, globalisation may also affect the outbreak of conflicts (Flaten \& de Soysa, 2012; Nieman, 2011). To explore this issue, we use an alternative dependent variable which is coded one for the first year of a conflict episode (PRIO25 definition) that follows at least 2 years of peace, zero otherwise. The onset regressions are displayed in Table S7 in the online Appendix S1. The results are very similar to those described above for conflict incidence. Our estimates reveal that there is no evidence for a significant effect of globalisation on conflict outbreak. The only exception is the measure of social globalisation, whose coefficient is negative and statistically significant at the $10 \%$ level in column 3 of Table S7. This suggests that this aspect of globalisation may contribute to reducing the risk of conflict onset, although its effect is not statistically significant in the specification including all dimensions of globalisation jointly (column 5 of Table S7).

\section{6 | CONCLUSIONS}

Civil conflicts account for an enormous share of deaths and hardship in the world today. In addition to the direct impact on battle-related deaths, intrastate conflicts give rise to an important number of indirect deaths due to disease and malnutrition, as well as the forced displacement of refugees. It is estimated that civil wars have caused three times as many deaths as wars between states since the end of the Second World War (Fearon \& Laitin, 2003). Intrastate conflicts also have a negative impact on political stability and economic development. Therefore, the analysis of the explanatory factors of internal conflicts is particularly relevant. In view of this, in this paper we have investigated the link between globalisation and civil conflict using data on 159 countries over the period 19722009. Unlike most of the existing studies on this issue, this paper employs an extensive notion of globalisation including its three main dimensions: economic, social and political integration.

The results show that the inclusion of country fixed effects removes the statistical association between the degree of integration with the rest of the world and the incidence of internal conflict.

\footnotetext{
${ }^{11}$ As shown in Table S5 in the online Appendix S1, the main results of the paper remain unaffected if we consider alternatively the average incidence of conflict in neighbouring countries over the last 5 years.
} 
We present instrumental variables estimates that also show no causal effect of globalisation on civil conflict. These findings do not depend either on the specific dimension of globalisation considered or the measure of conflict used in the analysis. Likewise, the absence of a relationship between globalisation and civil conflict is not driven by countries located in the most conflictive regions in the world.

The conclusions of the paper shed considerable doubt on those arguments that claim the existence of a direct link between globalisation and conflict. Nevertheless, some caution is necessary in interpreting our results. First, it is important to note that our findings do not allow us to dismiss the possibility that the impact of globalisation on conflict might be conditional on factors such as ethnic heterogeneity, horizontal inequalities or natural resource abundance. Further research is required to explore the relevance of these potential interaction effects. Second, the various arguments laid down in Section 2 show that the relationship between globalisation and civil conflict is far from simple and involves multiple factors and mechanisms that often work in opposite directions. Additional analyses are required to isolate and quantify the relevance of the different transmission channels which may link the degree of integration with conflict. Only by pursuing these strands will we be able to attain a more complete understanding of the relationship between globalisation and civil conflict.

\section{ACKNOWLEDGEMENTS}

The authors would like to thank one anonymous referee, Joan Esteban, Carmen Herrero, Javier Hualde, Sara Martínez de Morentín, Laura Mayoral, Fidel Pérez, Prakarsh Singh and participants at the 17th World Congress of the International Economic Association and the 14th Conference on International Economics for their useful comments and suggestions to earlier versions of the paper. This research has benefited from the financial support of the Spanish Ministry of Economy and Competitiveness (Projects ECO2011-29314-C02-01 and ECO2015-64330-P).

\section{REFERENCES}

Anderson, J. E., \& Van Wincoop, E. (2004). Trade costs. Journal of Economic Literature, 42, 691-751.

Angrist, J. D., \& Kreuger, A. B. (2001). Instrumental variables and the search for identification: From supply and demand to natural experiments. The Journal of Economic Perspectives, 15, 69-85.

Antweiler, W., Copeland, B. R., \& Taylor, M. S. (2001). Is free trade good for the environment? American Economic Review, 91, 877-908.

Barbieri, K., \& Reuveny, R. (2005). Economic globalization and civil war. Journal of Politics, 67, $1228-1247$.

5 Beck, N., \& Katz, J. N. (2004). Time-series cross-section issues: Dynamics, 2004 . Unputhishect

Bhagwati, J. (2004). In defense of alobalization. New York, NY: Oxford University Press.

Blattman, C., \& Miguel, E. (2010). Civil war. Journal of Economic Literature, 48, 3-57.

Bosker, M., \& de Ree, J. (2014). Ethnicity and the spread of civil war. Journal of Development Economics, 108, 206-221.

Brown, M. E. (1996). The international dimension of internal conflicts. Cambridge, MA: MIT Press.

Brunnschweiler, C. N., \& Bulte, E. H. (2009). Natural resource and violent conflict: Resource abundance, dependence and the onset of civil wars. Oxford Economic Papers, 61, 651-674.

Buhaug, H., \& Gleditsch, K. S. (2008). Contagion or confusion? Why conflicts cluster in space. International Studies Quarterly, 52, 215-233.

Bussmann, M., \& Schneider, G. (2007). When globalization discontent turns violent: Foreign economic liberalization and internal war. International Studies Quarterly, 51, 79-97.

Chua, A. (2003). World on fire. How exporting free market democracy breeds ethnic hatred and global instability. New York, NY: Anchor Books. 
Clark, W. C. (2000). Environmental globalization. In J. S. Nye \& J. D. Donahue (Eds.), Governance in a globalizing world (pp. 86-108). Washington, DC: Brookings Institution Press.

Collier, P., \& Hoeffler, A. (2004). Greed and grievance in civil war. Oxford Economic Papers, 56, 563-595.

Collier, P., Hoeffler, A., \& Rohner, D. (2009). Beyond greed and grievance: Feasibility and civil war. Oxford Economic Papers, 61, 1-27.

Deiwiks, C., Cederman, L., \& Gleditsch, K. S. (2012). Inequality and conflict in federations. Journal of Peace Research, 49, 289-304.

Disdier, A. C., \& Head, K. (2008). The puzzling persistence of the distance effect on bilateral trade. Review of Economics and Statistics, 90, 37-48.

Disdier, A. C., Tai, S., Fontagné, L., \& Mayer, T. (2010). Bilateral trade of cultural goods. Review of World Economics, 145, 575-595.

Doces, J. A., \& Magee, C. S. (2015). Trade and democracy: A factor-based approach. International Interactions, 41, $407-425$.

Dollar, D., \& Kraay, A. (2004). Trade, growth and poverty. Economic Journal, 114, $22-49$.

Dreher, A. (2006). Does globalization affect growth? Evidence from a new index of globalization. Applied Economics, 38, 1091-1110.

Dreher, A., Gassebner, M., \& Siemers, L. H. (2012). Globalization, economic freedom and human rights. Journal of Conflict Resolution, 56, 509-539.

Dreher, A., \& Gaston, N. (2007). Has globalization really had no effect on unions? Kyklos, 60, $165-186$.

Dreher, A., Gaston, N., \& Martens, P. (2008). Measuring globalization: Gauging its consequences. New York, NY: Springer.

Esteban, J., Mayoral, L., \& Ray, D. (2012a). Ethnicity and conflict: An empirical study. American Economic Review, 102, 1302-1342.

Esteban, J., Mayoral, L., \& Ray, D. (2012b). Ethnicity and conflict: Theory and facts. Science, 336, 858-865.

Ezcurra, R., \& Rodríguez-Pose, A. (2014). Does economic globalization affect spatial inequality? A cross-country analysis. World Development, 52, 92-103.

Fearon, J., \& Laitin, D. (2003). Ethnicity, insurgency, and civil war. American Political Science Review, 97, 75-90.

Findlay, R., \& O'Rourke, K. H. (2007). Power and plenty: Trade, war and the world economy in the second millennium. Princeton, NJ: Princeton University Press.

Flaten, R. D., \& de Soysa, I. (2012). Globalization and political violence, 1970-2008. International Interactions, 38, $622-646$.

Frankel, J. A., \& Romer, D. (1999). Does trade cause growth? American Economic Review, 89, 379-399.

Frankel, J. A., \& Rose, A. K. (2005). Is trade good or bad for the environment? Sorting out the causality. Review of Economics and Statistics, 87, 85-91.

Fujita, M., \& Thisse, J. F. (2002). Economics of agglomeration: Cities, industrial location and regional growth. Cambridge, UK: Cambridge University Press.

Goldberg, P. K., \& Pavcnik, N. (2007). Distributional effects of globalization in developing countries. Journal of Economic Literature, 45, 39-82.

Gurr, T.R. (2000). People versus states: Minorities at risk in the new tute-of Peace Press.

Hegre, H., Ellingsen, T., Gates, S., \& Gleditsch, N. P. (2001). Toward a democratic civil peace? Democracy, political change, and civil war, 1816-1992. American Political Science Review, 95, 33-48.

Hegre, H., \& Sambanis, N. (2006). Sensitivity analysis of empirical results on civil war onset. Journal of Conflict Resolution, 50, 508-535.

Heston, A., Summers, R., \& Aten, B. (2011). Penn world table version 7.0. ?????: Center for International Comparisons of Production, Income and Prices at the University of Pennsylvania. June, 2011.

Judson, R. A., \& Owen, A. L. (1999). Estimating dynamic panel data models: A guide for macroeconomists. Economics Letters, 65, 9-15.

Keohane, R. O., \& Nye, J. S. (2000). Introduction. In J. S. Nye \& J. D. Donahue (Eds.), Governance in a globalizing world (pp. 1-44). Washington, DC: Brookings Institution Press.

Krugman, P. (1998). What's new about the new economic geography? Oxford Review of Economic Policy, 14, 717. 
Lake, D., \& Rothchild, D. (1998). The international spread of ethnic conflict: Fear, diffusion and escalation. Princeton, NJ: Princeton University Press.

Martin, P., Mayer, T., \& Thoenig, M. (2008). Civil war and international trade. Journal of the European Economic Association, 6, 541-550.

Miguel, E., Satyanath, S., \& Sergenti, E. (2004). Economic shocks and civil conflict: An instrumental variables approach. Journal of Political Economy, 112, 725-753.

Milanovic, B. (2005). Can we discern the effect of globalization on income distribution? Evidence from household surveys. The World Bank Economic Review, 19, 21-44.

Milanovic, B. (2016). Global inequality: A new approach for the age of globalization. Cambridge, MA: Harvard University Press.

Montalvo, J. G., \& Reynal-Querol, M. (2005). Ethnic polarization, potential conflict and civil war. American Economic Review, 95, 796-816.

Nickell, S. J. (1981). Biases in dynamic models with fixed effects. Econometrica, 49, 1417-1426.

Nieman, M. D. (2011). Shocks and turbulence: Globalization and the occurrence of civil war. International Interactions, 37, 263-292.

Norris, P. (2000). Global Governance and Cosmopolitan Citizens. In J. S. Nye \& J. D. Donahue (Eds.), Governance in a globalizing world (pp. 155-177). Washington, DC: Brookings Institution Press.

Nunn, N., \& Qian, N. (2014). US food aid and civil conflict. American Economic Review, 104, 1630-1666.

Olzak, S. (2011). Does globalization breed ethnic discontent? Journal of Conflict Resolution, 55, 3-32.

Østby, G., Nordås, R., \& Rød, J. K. (2009). Regional inequalities and civil conflict in Sub-Saharan Africa. International Studies Quarterly, 53, 301-324.

Prakash, A., \& Hart, J. (1999). Globalization and governance: An introduction. In A. Prakash \& J. Hart (Eds.), Globalization and governance (pp. 1-24). London: Routledge.

Rivers, D., \& Vuong, Q. H. (1988). Limited information estimators and exogeneity tests for simultaneous probit models. Journal of Econometrics, 39, 347-366.

Rodrik, D. (2012). The globalization paradox: Democracy and the future of the world economy. New York, NY: W. W. Norton \& Company.

Ross, M. (2006). A closer look at oil, diamonds and civil war. Annual Review of Political Science, 9, 265-300.

Rudra, N. (2005). Globalization and the strengthening of democracy in the developing world. American Journal of Political Science, 49, 704-730.

Sen, A. (1973). On economic inequality. Oxford: Clarendon Press.

Sorens, J., \& Ruger, W. P. (2014). Globalisation and intrastate conflict: An empirical analysis. Civil Wars, 16, 381401.

Stiglitz, J. E. (2002). Globalization and its discontents. New York, NY: W. W. Norton \& Company.

Sunde, U., \& Cervellatti, M. (20RQ.1Bemocratizing for peace? The effect of democratization on civil conflicts. Oxford Economic Papers,

Tomohara, A., \& Takii, S. (2011). Does globalization benefit developing countries? Effects of FDI on local wages. Journal of Policy Modeling, 33, 511-521.

Wimmer, A., Cederman, L. E., \& Min, B. (2009). Ethnic politics and armed conflict: A configurational analysis of new global data set. American Sociological Review, 74, 316-337.

\section{SUPPORTING INFORMATION}

Additional Supporting Information may be found online in the supporting information tab for this article.

How to cite this article: Ezcurra R, Manotas B. Is there a link between globalisation and civil conflict?. World Econ. 2017;00:1-19. https://doi.org/10.1111/twec.12514 


\section{Author Query Form}

\section{Journal: TWEC}

\section{Article: 12514}

Dear Author,

During the copy-editing of your paper, the following queries arose. Please respond to these by marking up your proofs with the necessary changes/additions. Please write your answers on the query sheet if there is insufficient space on the page proofs. Please write clearly and follow the conventions shown on the attached corrections sheet. If returning the proof by fax do not write too close to the paper's edge. Please remember that illegible mark-ups may delay publication.

Many thanks for your assistance.

\begin{tabular}{|c|c|c|}
\hline Query reference & Query & Remarks \\
\hline 1 & $\begin{array}{l}\text { AUTHOR: Please confirm that given names (red) and surnames/family } \\
\text { names (green) have been identified correctly. }\end{array}$ & $\mathrm{OK}$ \\
\hline 2 & AUTHOR: Please define IMF. & ary Fund \\
\hline 3 & AUTHOR: Please define KOF. & sation \\
\hline 4 & AUTHOR: Please define OLS. & quare \\
\hline 5 & $\begin{array}{l}\text { AUTHOR: Please update this reference 'Beck and Katz (2004)' with missing } \\
\text { details. }\end{array}$ & \\
\hline 6 & $\begin{array}{l}\text { AUTHOR: Gurr (2000) has not been cited in the text. Please indicate where } \\
\text { it should be cited; or delete from the Reference List. }\end{array}$ & \\
\hline 7 & $\begin{array}{l}\text { AUTHOR: Please provide the publisher location for reference Heston et al. } \\
\text { (2011). }\end{array}$ & \\
\hline 8 & $\begin{array}{l}\text { AUTHOR: Please update this reference 'Sunde and Cervellatti (2014)' with } \\
\text { missing details. }\end{array}$ & \\
\hline
\end{tabular}




\section{Funding Info Query Form}

Please confirm that the funding sponsor list below was correctly extracted from your article: that it includes all funders and that the text has been matched to the correct FundRef Registry organization names. If a name was not found in the FundRef registry, it may not be the canonical name form, it may be a program name rather than an organization name, or it may be an organization not yet included in FundRef Registry. If you know of another name form or a parent organization name for a "not found" item on this list below, please share that information.

\begin{tabular}{|l|l|l|l|}
\hline FundRef name & $\begin{array}{l}\text { FundRef Organization } \\
\text { Name (Country) }\end{array}$ & FundRef DOI & Grant IDs \\
\hline $\begin{array}{l}\text { Spanish Ministry of } \\
\text { Economy and } \\
\text { Competitiveness }\end{array}$ & & & ECO2011-29314-C02-01 \\
\hline
\end{tabular}

